\title{
直交流中に流入する対向噴流における噴流干渉部分の非定常現象
}

\author{
長尾 隆央 ${ }^{* 1}$, 林 光一 ${ }^{* 2}$
}

\section{Unsteady behaviour of opposite impinging jets interaction in crossflow}

\author{
Takahisa NAGAO ${ }^{* 1}$ and A.Koichi HAYASHI ${ }^{* 2}$ \\ ${ }^{* 1}$ IHI Corporation \\ 1 Shin-Nakahara-Cho, Isogo-ku, Yokohama 235-8501, Japan \\ ${ }^{* 2}$ Department of Mechanical Engineering, Aoyama Gakuin University \\ 5-10-1 Fuchinobe, Chuo-ku, Sagamihara-shi, Kanagawa 252-5258, Japan
}

Received: 25 May 2016; Revised: 9 August 2016; Accepted: 30 November 2016

\begin{abstract}
A mixing of fuel with air in jet engine is studied by analyzing unsteady turbulent flow in a simplified flow channel which consists of the opposed jets in a cross-flow. The mixing behaviors of the flow have been investigated parametrically by using a momentum flux ratio between jet and cross-flow to find that the mixing performance was related with the momentum flux ratio. It was also suggested that the mixing performance was connected with the flow behavior of the opposing jets in their interaction area. Presently the frequency analysis is performed to elucidate the characteristics of unsteady opposed jets in a cross-flow. The results show that the Kelvin-Helmholtz instability and low frequency fluctuation exist in the opposed impinging jets. The strength of the K-H instability is about one-tenth of the low frequency fluctuation. The low frequency fluctuation is related to the circulation which is caused from the collision between opposed jets.
\end{abstract}

Key words : Jet engine, Combustor, Opposed jets, Mixing, LES

\section{1. 緒言}

ガスタービンエンジンにおいて，高効率化のためにタービン入口温度は年々上昇傾向にある。しかし，温度分 布が一様でない場合は，平均温度よりも高い温度ピークが存在することになり，タービンの寿命に影響を与える ことが懸念される，そのため，燃焼器の出口温度分布は十分に一様であることが望ましい．

図 1 にターボジェットエンジンと RQL 燃焼器の概略図を示寸. 燃焼器の形状は, 図 1(b)の断面を図 1(a)に示し たタービン軸で回転させた環状の形状となっている。燃焼器内部では，ノズルから噴射された燃料がスワール保 炎器で空気と混合して燃焼する，その直後，希釈空気が流入し，この過濃燃焼ガスと混合し，残りの燃料を燃焼 させる，燃焼器の温度分布は，希釈空気によって調整されるため，希釈空気流れを理解することは重要である．

希釈空気による流れは，主流に直交に流入する噴流として簡略化され，古くから検討されている．Lefebvre ら (2010)によると，Holdemann ら (1973)は，図 2 のような流路について研究を行い，孔形状，孔径 $D$, 孔間隔 $S$, 高 さ $H$, 噴流と主流の運動量流束比(momentum flux ratio) $J$ を変えた場合の混合状態を研究した．運動量流束比 $J$ は 次の式で表される.

$$
J=\frac{\rho_{j} u_{j}^{2}}{\rho_{m} u_{m}^{2}}
$$

ここで $\rho:$ 密度， $u$ :流速，添字 $j:$ 噴流，添字 $m$ :主流

No.16-00238 [DOI:10.1299/transjsme.16-00238], J-STAGE Advance Publication date : 13 December, 2016

*1 正員, (株) IHI（广235-8501 神奈川県横浜市磯子区新中原町 1)

*2 正員，フェロー，青山学院大学 機械創造工学科（广252-5258 神奈川県相模原市中央区淵野辺 5-10-1）

E-mail of corresponding author: takahisa nagao@ihi.co.jp 
Liscinsky ら(1992)は実験により，Jが大きいほど混合が良いと報告している. 我々の研究(Nagao et al.,2014)にお いても同様の結果が得られており，非定常 CFD 解析を利用することで，Jの大きさが変化するにつれ，流れ場の 混合の形態も変化することが示唆される結果を得た．要点を述べると，図 3 に示すように，直交流に対する噴流 の運動量流束比 $J$ が大きい場合は，噴流同士が強く衝突することで衝突面に円盤状ジェットが生成し，円盤状ジ エットの部分で混合が促進される $(J=64), J$ が若干小さい場合は，上下噴流が衝突する部分でスイッチングのよ うに非定常に変動することで, 噴流の成分が分散することで混合が促進される $(J=9,16)$, 直交流に対する噴流の貫 通度が弱い場合は，噴流同士の干渉が弱く，混合にはあまり影響を与えない $(J=4)$ というような現象を報告してい る. ただし，混合挙動の分類は主に噴流可視化画像によるもので，分析が十分と言えなかった.

そこで，本論文では，直交流中の対向衝突噴流混合流れにおいて，Jを変化させた場合の噴流衝突部分におけ る速度変動特性を数值流体解析により分析することで，流れの非定常特性を明らかにすることを目的とする.

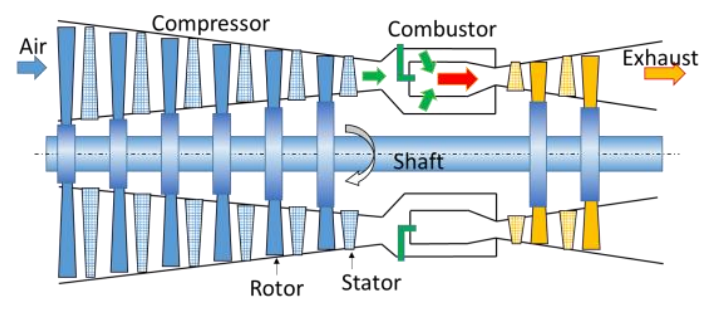

(a) turbo jet engine (cutaway drawing)

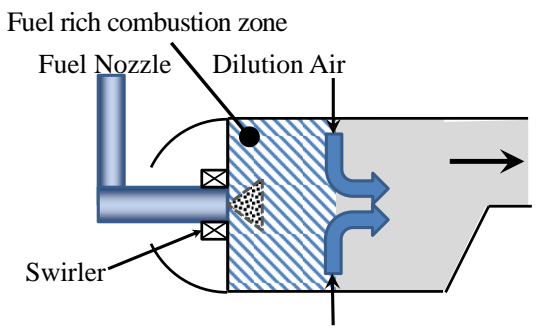

(b) combustor

Fig.1 Schematics of RQL gas turbine combustor.

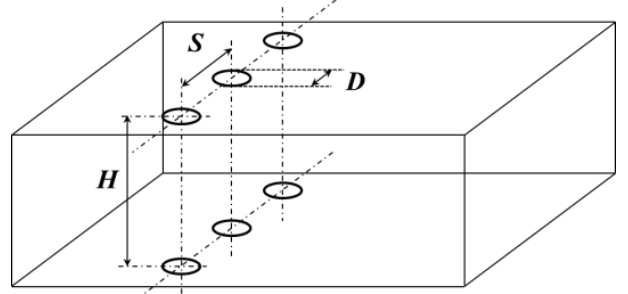

Fig.2 Explanation of geometric parameters $S, H, D$.

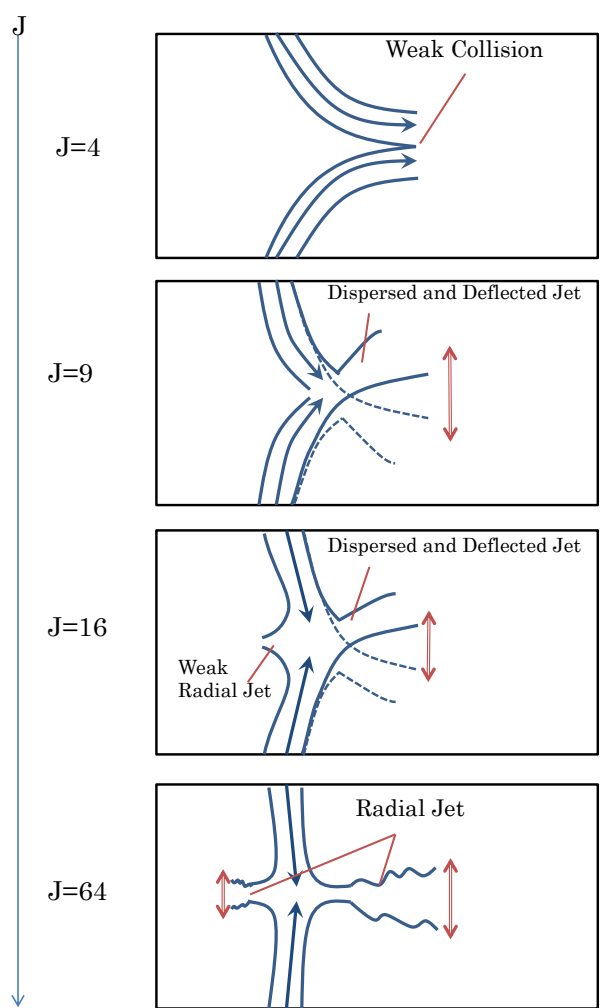

Fig.3 Mixing mechanisms of jets in crossflow. $(S / D=5, H / D=5))($ Nagao et al.,2014)

\section{2. 対象形状 - 解析モデル}

流路構成としては，背景でのべたとおり，以前の我々の研究(長尾・林,2015)と同じように，矩形流路に直交す る対向噴流を有する流れを採用した。噴流口は $Z$ 方向（奥行き方向）の中間に位置している. 図 4 に対象とする 形状を示す． $D$ は噴流孔径， $S$ は噴流孔間隔， $H$ は流路高さ， $V_{j}$ は噴流流速， $V_{m}$ は主流流速， $X_{j}$ は主流入口と噴 流孔の距離である. $X, Y, Z$ 軸の原点位置は上下噴流流入口中心線上の中間点である. 図上で $S$ は流路幅として表示 されているが，手前側と奥側の境界に周期境界を設定しているため，噴流孔間隔も $S$ となる.

流路の左端から主流が流入する. 右端は大気開放である. 噴流流速と径を基準としたレイノルズ数は約 $2.0 \times 10^{4}$ である(噴流径 $D=20 \mathrm{~mm}$ ). 流入流速は一様とした，今回は流路形状が同一の条件の下で，Jを変化させた解析を 
実施した. 設定条件の一覧を表 1 に示寸. 噴流流速はすべての条件で同一 $\left(V_{j}=20 \mathrm{~m} / \mathrm{s}\right)$ とし, 主流流速 $V_{m}$ を変化さ せている.

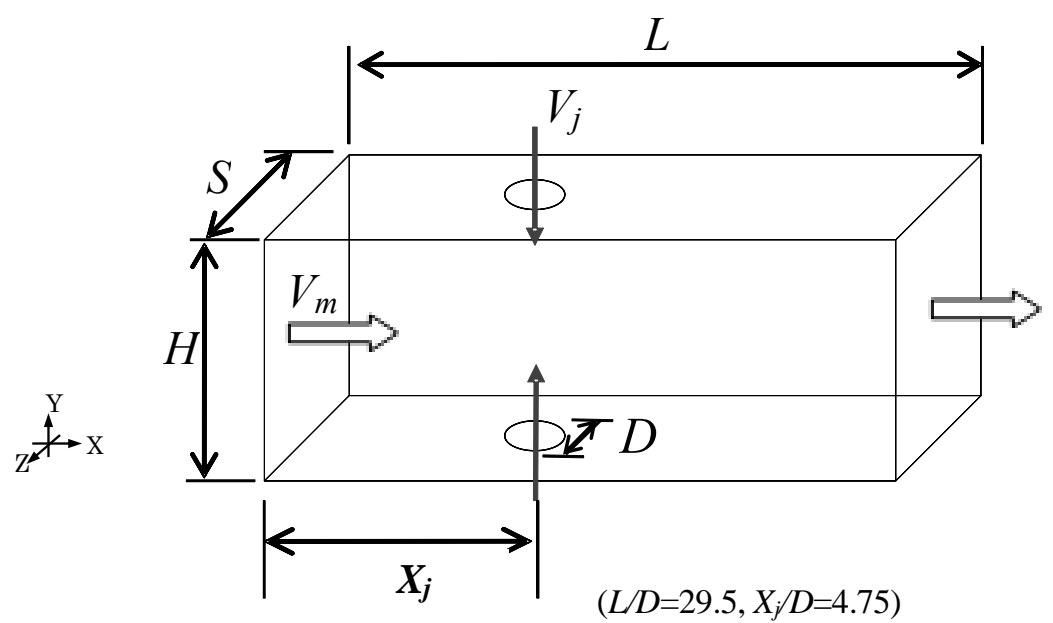

Fig.4 Outline of flow passage configuration.

Table 1 Conditions of calculated cases.

\begin{tabular}{|l|l|l|l|}
\hline & $S / D$ & $H / D$ & $J$ \\
\hline 1 & 5.0 & 5.0 & 4 \\
\hline 2 & 5.0 & 5.0 & 9 \\
\hline 3 & 5.0 & 5.0 & 16 \\
\hline 4 & 5.0 & 5.0 & 36 \\
\hline 5 & 5.0 & 5.0 & 64 \\
\hline
\end{tabular}

\section{3. 数值解析手法}

\section{$3 \cdot 1$ 解析手法}

数值解析には OpenFOAM 2.1.0 の reactingFoam を使用した. OpenFOAM は広く利用されており, 例えば, 密度 の異なるガスの乱流混合を検証した研究(Mack and Spriokt,2013)や，超音速主流中に流入する直交噴流の燃焼解析 (Shekarian et al.,2014)等の研究に使われており，実験と定量的に一致したと報告されている.

表 2 に計算モデルを示す，気体の物性は主流と噴流で同一とするが，混合を評価するため独立した化学種とし て扱う。支配方程式には Navier-Stokes 方程式を用い，乱流の扱いについては Large Eddy Simulation モデルを採用 した. フィルタを行った連続の式, 運動方程式, 物質拡散・エネルギーの式は以下になる(Poinsot and Veynante, 2005).

$$
\begin{aligned}
& \frac{\partial \bar{\rho}}{\partial t}+\frac{\partial}{\partial x_{i}}\left(\bar{\rho} \widetilde{u_{l}}\right)=0 . \\
& \frac{\partial \bar{\rho} \widetilde{u_{l}}}{\partial t}+\frac{\partial}{\partial x_{i}}\left(\bar{\rho} \widetilde{u_{l}} \widetilde{u_{\jmath}}\right)+\frac{\partial \bar{p}}{\partial x_{j}}=\frac{\partial}{\partial x_{i}}\left(\overline{\tau_{i j}}-\bar{\rho}\left(\widetilde{u_{l} u_{\jmath}}-\widetilde{u_{l}} \widetilde{u_{J}}\right)\right) . \\
& \frac{\partial \bar{\rho} \widetilde{Y_{k}}}{\partial t}+\frac{\partial}{\partial x_{i}}\left(\bar{\rho} \widetilde{u_{l}} \widetilde{Y_{k}}\right)=\frac{\partial}{\partial x_{i}}\left(\bar{\rho} \bar{D}_{k} \frac{\partial \widetilde{Y_{k}}}{\partial x_{i}}-\bar{\rho}\left(\widetilde{u_{l} \widetilde{Y}_{k}}-\widetilde{u_{l}} \widetilde{Y_{k}}\right)\right)+\overline{\omega_{k}} \quad \mathrm{k}=1, \ldots, \mathrm{N} . \\
& \frac{\partial \bar{\rho} \widetilde{h_{s}}}{\partial t}+\frac{\partial}{\partial x_{i}}\left(\bar{\rho} \widetilde{u_{l}} \tilde{h}_{s}\right)=\frac{\partial \bar{p}}{\partial t}+\overline{u_{l} \frac{\partial p}{\partial x_{l}}}+\frac{\partial}{\partial x_{i}}\left(\bar{\lambda} \frac{\partial \widetilde{T}}{\partial x_{i}}-\bar{\rho}\left(\widetilde{u_{l} h_{s}}-\widetilde{u_{l}} \tilde{h}_{s}\right)\right)+\overline{\omega_{T}} .
\end{aligned}
$$

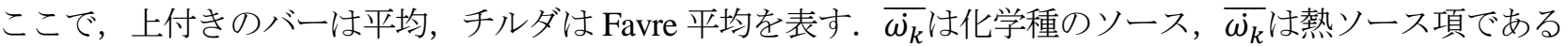
が，本解析では燃焼は考慮しないため 0 となる. 式(4)において, Soret 効果と圧力拡散は無視される. $\bar{D}_{k}$ は 物質拡散係数であり, 本コードでは物質拡散係数と粘性係数は同一の值と仮定している(シュミット数 
$\left.\mathrm{Sc}=\mu / \rho D_{k}=1\right)$. 式(5)において, 熱伝導率入はプラントル数 $\operatorname{Pr}$ を用いて $\lambda=C_{p} \mu / \operatorname{Pr}$ から計算され, $\operatorname{Pr}=1.0$ とした.また, 乱流加熱については本解析の領域では十分小さいために無視される.ルイス数をLe $=\mathrm{Sc} / \mathrm{Pr}=$ 1としており，多成分混合による熱拡散項は無視される(Hallagi, M. and Mazaheri,2011).

サブグリッド乱流モデルに関連する未解決の SGS 応力 $\sigma_{i j}$ は次のようになる.

$$
\sigma_{i j}=\left(\widetilde{u_{\imath} u_{\jmath}}-\widetilde{u_{\imath}} \widetilde{u_{\jmath}}\right) \text {. }
$$

SGS 応力は Smagorinsky モデルが使用され，以下のようになる(Poinsot and Veynante, 2005).

$$
\begin{aligned}
& \sigma_{i j}-\frac{\delta_{i j}}{3} \sigma_{k k}=-\mu_{S G S}\left(\frac{\partial \overline{u_{i}}}{\partial x_{j}}+\frac{\partial \overline{u_{j}}}{\partial x_{i}}\right)=-2 \mu_{S G S} \overline{S_{l j}}, \mu_{S G S}=\left(C_{S} \Delta\right)^{2}\left(2 \bar{S}_{i j} \bar{S}_{i j}\right)^{\frac{1}{2}} . \\
& \Delta=\sqrt[3]{\Delta x \Delta y \Delta z}, .
\end{aligned}
$$

ここで, openFoam では以下のように定義される. $\mathrm{C}_{\mathrm{k}}, \mathrm{C}_{\mathrm{e}}$ は定数であり， $\mathrm{C}_{\mathrm{k}}=0.094, \mathrm{C}_{\mathrm{e}}=1.048$ とした $\left(\mathrm{C}_{\mathrm{s}}=0.2\right)$.

$$
C_{s}^{2}=C_{k} \sqrt{\frac{2 C_{k}}{C_{e}}}, k=\sigma_{k k} / 2=\frac{2 C_{k}}{C_{e}} \Delta^{2}\left|{\overline{S_{l j}}}^{2}\right| .
$$

(9)

サブグリッドスケールの物質・熱流束は以下のようになる.

$$
\bar{\rho}\left(\widetilde{u_{l} \widetilde{Y}_{k}}-\widetilde{u_{l}} \widetilde{Y_{k}}\right)=\frac{\mu_{S G S}}{S c_{t}} \frac{\partial \tilde{Y}}{\partial x_{i}}, \quad \bar{\rho}\left(\widetilde{u_{\imath} h_{S}}-\widetilde{u}_{\imath} \tilde{h}_{S}\right)=\frac{\mu_{S G S}}{P r_{t}} \frac{\partial \widetilde{h}_{S}}{\partial x_{i}} .
$$

ここで， $\mathrm{Sc}_{\mathrm{t}}$ は乱流シュミット数， $\mathrm{Pr}_{\mathrm{t}}$ は乱流プラントル数であり，本解析では $\mathrm{Sc}_{\mathrm{t}}=\mathrm{Pr}_{\mathrm{t}}=1.0$ とする.

Table 2 Numerical methods and mesh conditions.

\begin{tabular}{|l|l|}
\hline CFD code & OpenFOAM 2.1.0 reactingFOAM \\
\hline Equation & Navier-Stokes \\
\hline Turbulent model & Smagorinsky model (LES) \\
\hline Wall & Spalding law \\
\hline Cell & Unstructured, Hexahedron \\
\hline Discretization & $\begin{array}{l}\text { Blended 2nd order central with 1st order } \\
\text { upwind }(9: 1)\end{array}$ \\
\hline Parallelization & Region splitting, 100 CPUs \\
\hline Min., Ave $\Delta \mathrm{x}$ & $0.2 \mathrm{~mm}, 2 \mathrm{~mm}$ \\
\hline
\end{tabular}

\section{$3 \cdot 2$ 実験との比較}

図 5 に LDV による計測点位置, 図 6 に CFD 結果と LDVによる流速計測結果(長尾他,2013)との比較結果を示 す. $Z$ 方向位置は噴流中心とした，本実験では主流無し $\left(V_{m}=0\right)$ の条件であり，対向噴流同士の衝突が最も強い条 件である．軸対称噴流同士を衝突させた場合は，流れ場は軸対称になり，噴流軸上 $(X=0) の X$ 方向平均流速は 0 になるはずだが，今回の流れ場は，図７に示すように，噴流が上下より流入し，衝突する流れ場となる. 入口側 を閉止した矩形ダクト中に噴出しているため，左側壁面の影響で完全には対称とならない．噴流衝突後の流速分 布, 流速変動 RMS 共に LDV 計測結果と CFD は大部分でよい一致を示しており, 対向衝突噴流の解析に本手法 は妥当であると判断できる. 


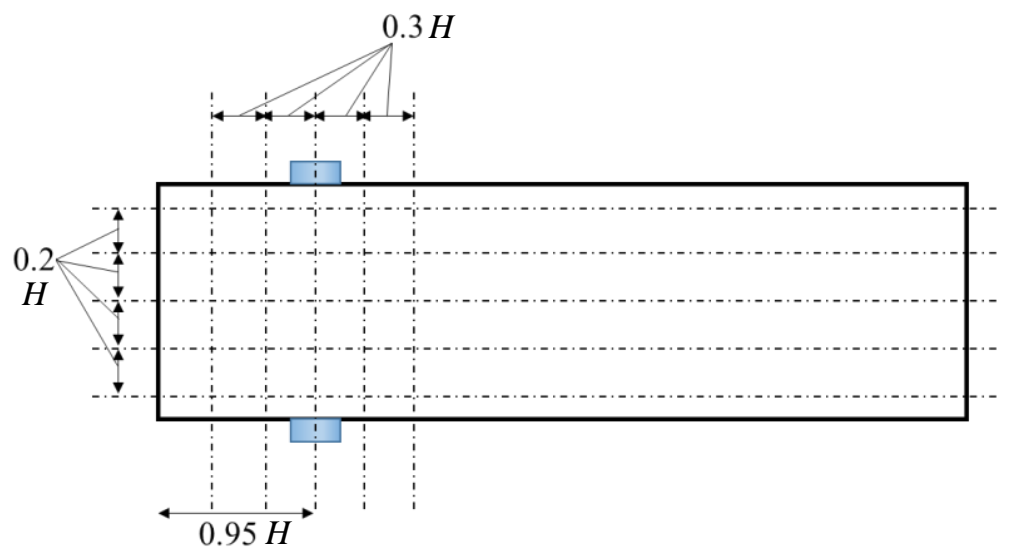

Fig.5 LDV measurement points.

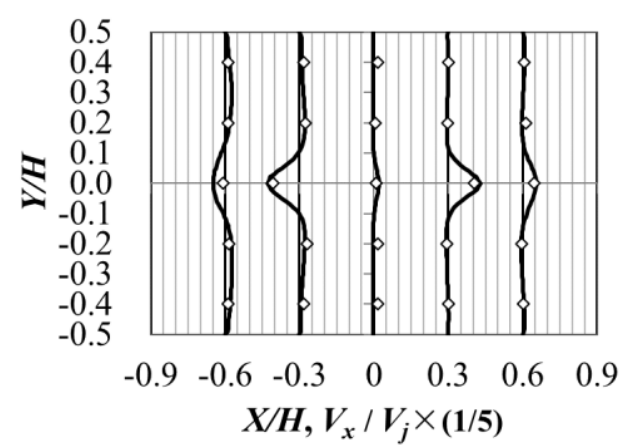

(a) Velocity of X-direction

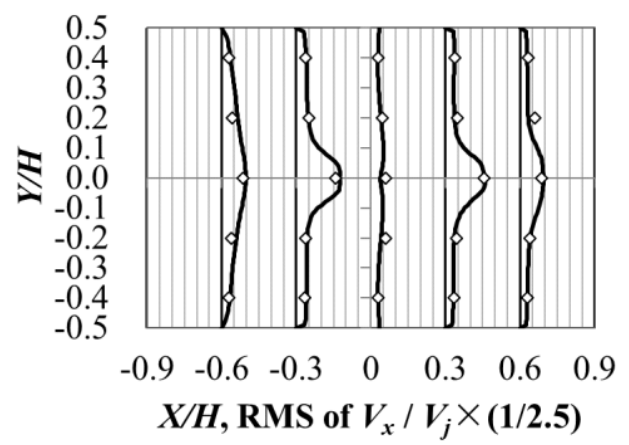

(c) RMS velocity of $X$-direction
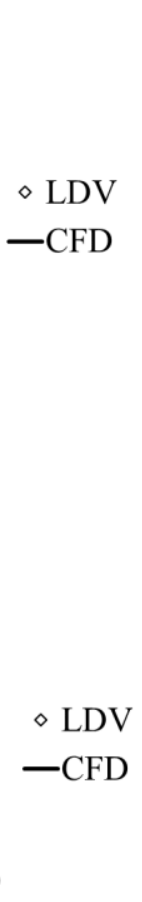

0.5
0.4
0.3
0.2
0.1
0.0
0.1
-0.1
-0.2
-0.3
-0.4
-0.5

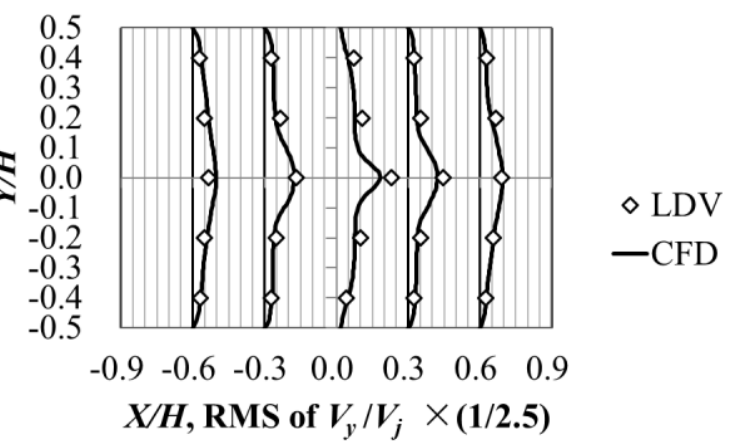

(d) Velocity RMS of $Y$-direction

Fig.6 Comparison of CFD results with LDV measurements.

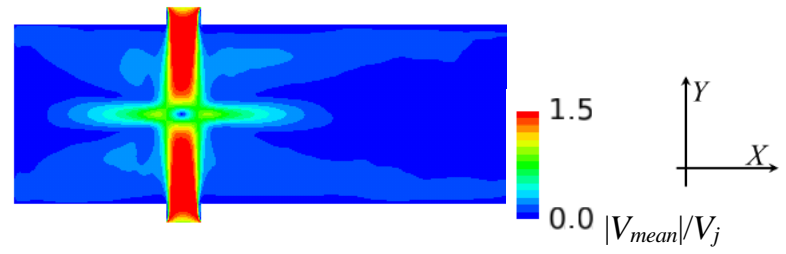

Fig.7 Time average of velocity magnitude $/ V_{j}$. 


\section{$3 \cdot 3$ 計算格子}

図 8 に解析格子を示す. 最小格子幅は $0.2 \mathrm{~mm}$, 流路内の平均格子幅は $X, Y, Z$ 方向共に $2 \mathrm{~mm}$ である. 格子点数は 約 300 万点となった．流路の左端から主流が流入し，右端から流出する. 噴流はオリフィス部を通過することで 生成される.オリフィス内部は約 $0.5 \mathrm{~mm}$ の格子サイズで構成され，直径方向に約 40 点の分割数を持つ. オリフ イスの厚さは $0.5 D$ であり，図 8 のように，オリフィス上流に $9.5 D \times 5 D \times 5 D(X \times Y \times Z$ 方向 $)$ の直方体形状の導入部 があり, 直方体の 1 面から一様に流入する.

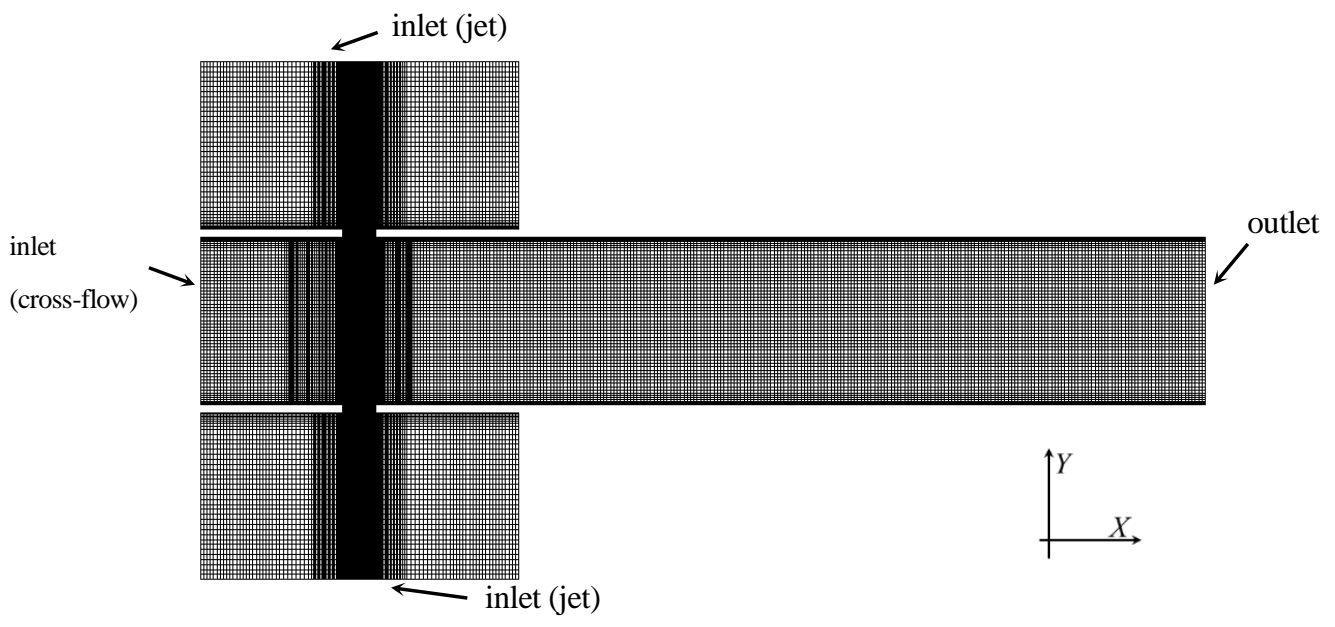

(a) Cross section at center of jet

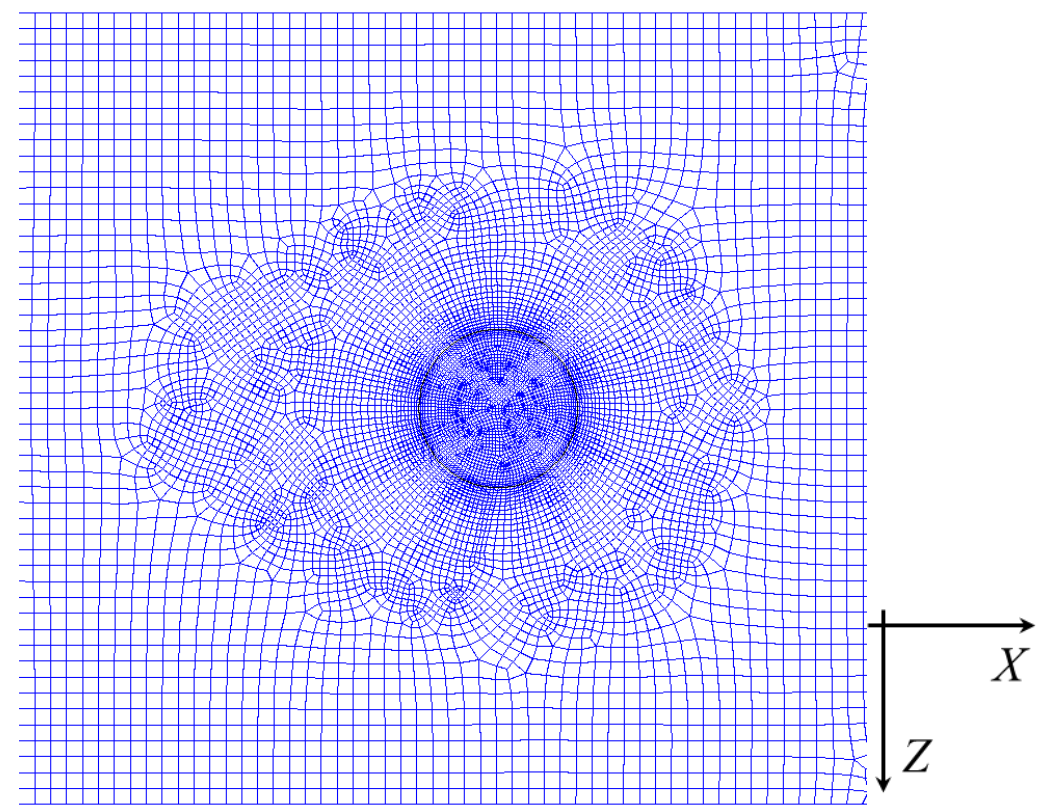

(b) Around jet orifice

Fig.8 Numerical mesh shape. 


\section{4. 結果と考察}

混合度合を評価するに当たり, Vranos ら(1991)は空間的な未混合度である Unmixedness $\left(U_{s}\right)$ という量を定義した。 Usは次の式で表される.

$$
U_{s}=\frac{C_{r m s}}{C_{a v g}}=\frac{\sqrt{\frac{1}{n} \sum_{\mathrm{i}=1}^{\mathrm{n}}\left(\bar{C}_{i}-C_{a v g}\right)^{2}}}{w_{m}\left(w_{j}+w_{m}\right)}
$$

$C_{r m s}$ は評価部位濃度 RMS, $C_{a v g}$ は完全混合時濃度, $\bar{C}_{i}$ は局所時間平均濃度, $w_{m}$ は主流流量, $w_{j}$ は噴流流量である. ここで， $C_{i}$ は，ガス種として主流と噴流を定義した時の主流の体積分率を表す． $U_{s}$ が減少するほど，断面内の濃 度分布が均一となり, 完全に均一になれば 0 となる.

混合は滞留時間に応じて進行する，そのため，平均流速が異なる条件間で比較を行う場合は，同じ位置ではな く, 同じ滞留時間となる断面で比較することが重要となる．滞留時間 $T_{r}$ を次のよう定義する.

$$
T_{r}=\frac{X}{(Q / A)}
$$

ここで, $X$ は主流方向位置, $Q=Q_{m}+Q_{j}, Q_{m}$ は主流体積流量, $Q_{j}$ は噴流体積流量, $A$ は流路断面積である.

\section{$4 \cdot 1$ 運動量流束比 Jの違いによる噴流衝突挙動と未混合度 $U_{s}$ の変化}

図 9 に対向衝突噴流の時系列可視化画像を示寸。上下噴流を異なる色で表し，各噴流成分の質量分率が 0.4 の 等值面を表示することで噴流形状を表している. 図 10 に滞留時間 $T_{r}=0.04$ 時点での未混合度と $J$ の関係を示寸.

緒言でも述べたとおり，我々の以前の研究(Nagao et al.,2014)において得られているように，Jによって流れ場の 形態が異なり，図 3 のような形態に分類できることを以前報告したが，今回の解析でも同様の結果が得られてい ることがわかる.

再度流れの特徵を述べると，図３に示すように，直交流に対する噴流の運動量流束比 $J$ が大きい場合は，噴流 同士が強く衝突することで衝突面に円盤状ジェットが生成し，円盤状ジェットの部分で混合が促進される $(J=64)$, $J$ が若干小さい場合は，上下噴流が衝突する部分でスイッチングのように非定常に変動することで, 噴流の成分 が分散することで混合が促進される $(J=9,16)$, 直交流に対する噴流の貫通度が弱い場合は, 噴流同士の干渉が弱く, 混合にはあまり影響を与えない $(J=4)$

今回新たに $J=36$ となる条件を追加した。 $J=36$ は， $J=64$ に比べて噴流同士の衝突面に生成される円盤状ジェッ 卜の形状が安定していないように見受けられるが, 図9に示したように, 未混合度 $U_{s}$ につては同様の值を示す。 このことから, $J=36$ においても, 図 3 における J=64 の形態と同じように円盤状ジェット部分での混合が主とな っていると判断できる. 


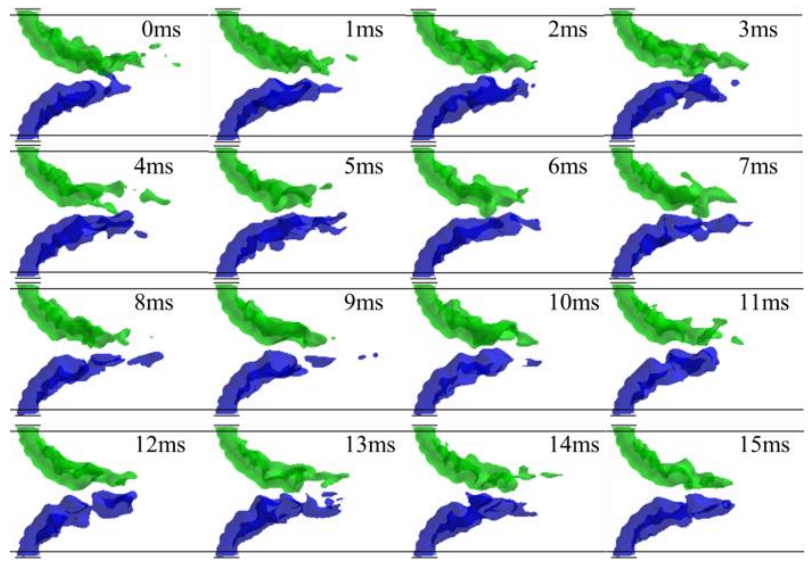

(a) $J=4$

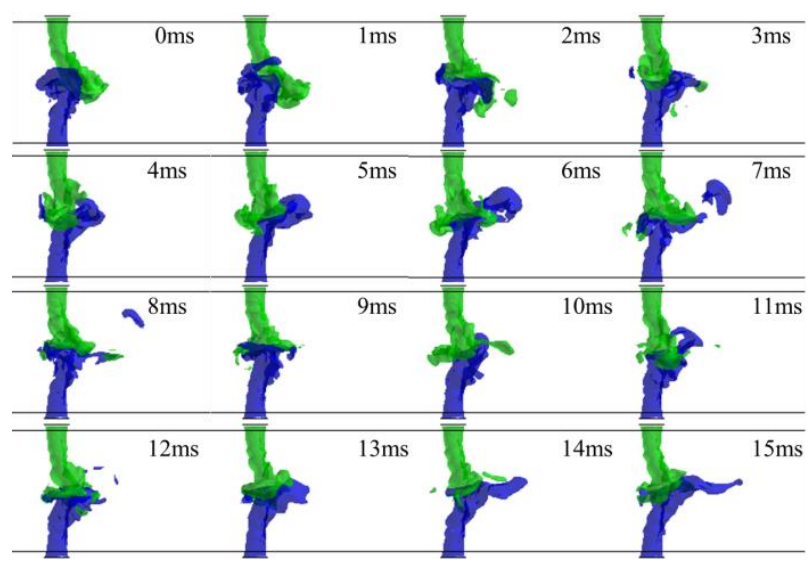

(c) $J=16$

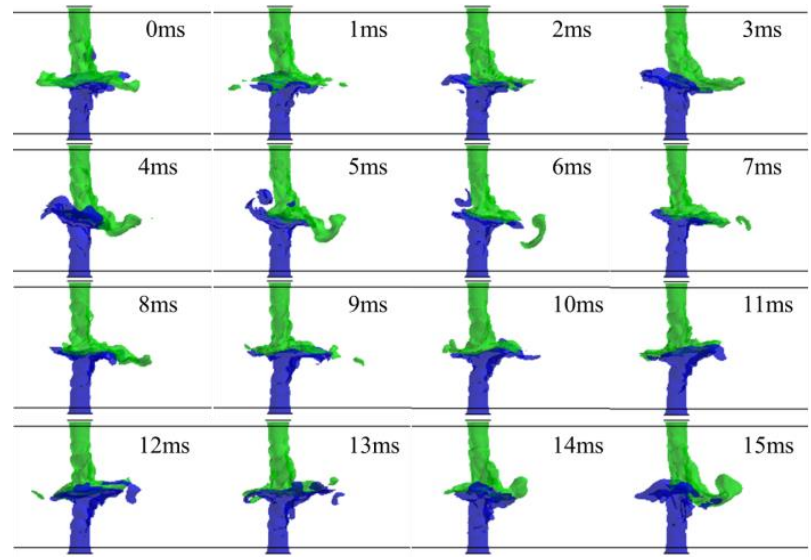

(e) $J=64$

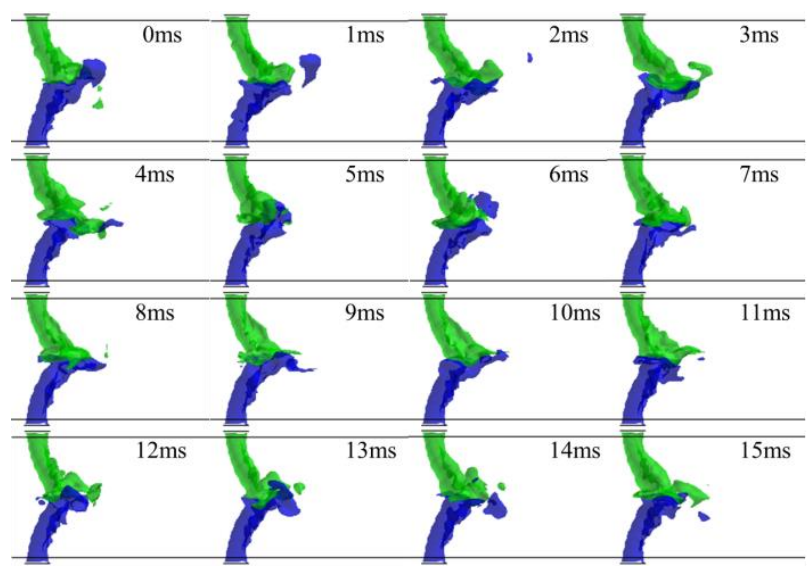

(b) $J=9$

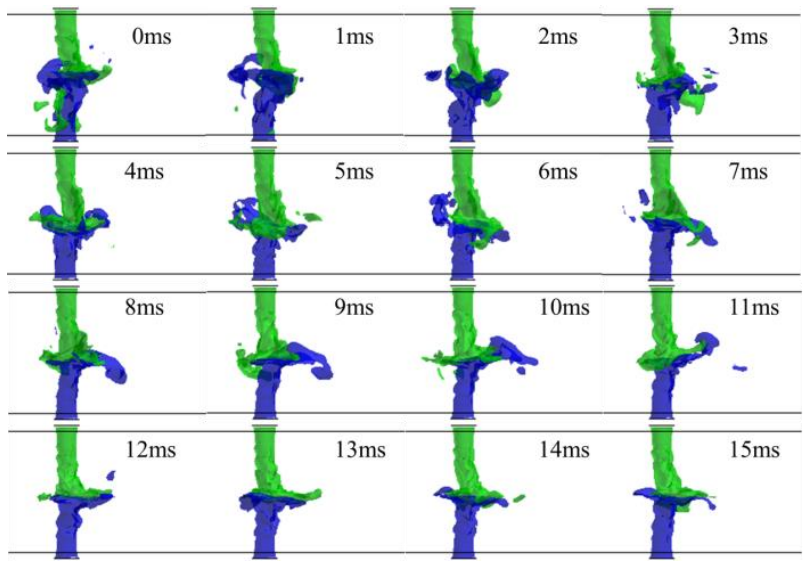

(d) $J=36$

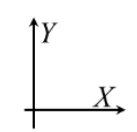

Fig.9 Time sequence images of the jet shape. 


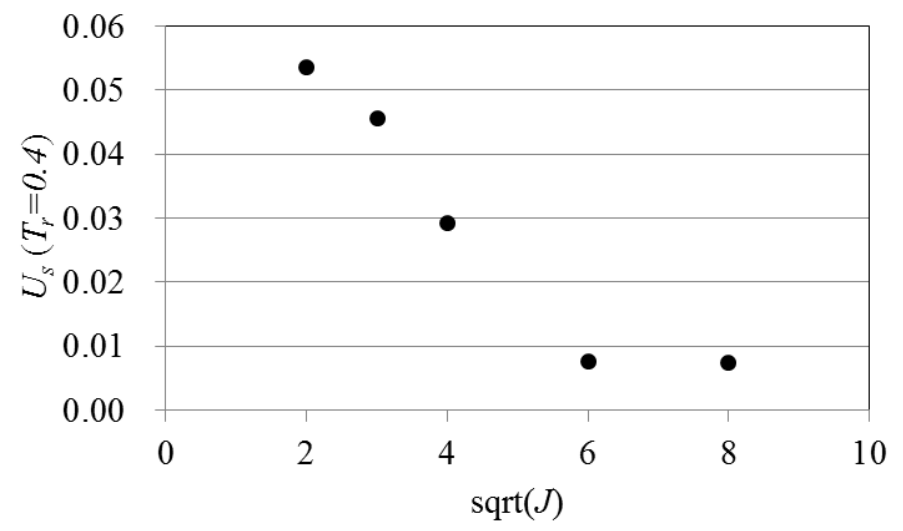

Fig.10 Relation between the momentum flux ratio and unmixedness at $T_{r}=0.04$

\section{$4 \cdot 2$ 対向噴流の速度変動解析}

図 11 に, 流路の代表点における $Y$ 方向流速変動のフーリエ変換結果を示す．ここで, 図 11(f)に示す通り, 噴 流出口を near jet inlet，流路中心付近の噴流衝突部を near collision area と示している. 図 11(a)〜(e)において, 太線 が噴流出口(縦軸第 2 軸:右側), 細線が噴流衝突部(縦軸第 1 軸:左側)のスペクトルを示している. 図 11 中に記され ている, C-f1,NJ-f1 などの記号は, 特徵的なピークを表したものであり, 表 3 に各ピークの周波数, 変動強度, 変動の分類（詳細は(d)に後述する）を示している.

(a) 噴流剪断層起因の変動

図 11 に示されるように，噴流付近における速度変動は $1100 〜 1600 \mathrm{~Hz}$ のピークがあることが分かる. 噴流を代 表流速とし，噴流径を代表径とした場合の最大ピークのストローハル数 St は $1.1 \sim 1.55$ となる. 図 12 に J=9 にお ける Z 軸周りの渦度分布の連続画像を示す. 図 12 から, 噴流に特徵的な周期的渦輪構造が確認でき, 周波数が $1200 \mathrm{~Hz}$ 以上あることが確認できる.

オリフィスから噴流が出る場合の剪断層におけるケルビン・ヘルムホルツ不安定性(以下 K-H)を起因とするス トローハル数は，一般的に約 $0.24 \sim 0.51$ となる(豊田,2005)ことが示されているが，我々と同じように直交流中の 噴流流れを扱っている Getsinger(2012)の研究においては, 直交流中の噴流における剪断層の計測結果は St=0.7〜 1.0 となっており, 単純噴流に比べて大きい值となっている. Getsingerによると, $\mathrm{St}=0.7 \sim 1.0$ が直交流中の噴流 の剪断層における基本振動周波数 $f_{0}$ であり, $J$ を無限大にしたケース（単純噴流と同じ）で観測される $S t=f_{0} / 2$ の 周波数は, 剪断による渦の形成が不安定になった結果であると記している. 一方, 豊田(2005)によると, 大規模

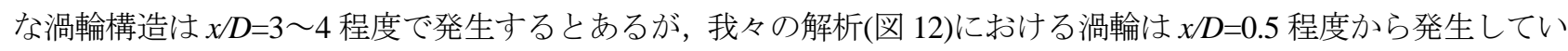
る(ここでの $x$ は噴流出口からの距離を表す)。豊田は, K-H 不安定性により発生した小規模な洞輪が合体して大 規模な洞輪となるとしており, 我々の解析結果においても, 渦の合体が発生していることが示されている(図 12). 本研究や Getsinger らの研究で表れている渦輪は, 小規模な渦輪が, 単純噴流より早い段階で大規模渦に変化した 結果と推測できる．K-H に起因する渦は合体により周波数が 1/2 となっていくことが知られており(Fric,1990), 本解析や Getsinger の研究における渦輪の周波数が高い原因は，渦合体過程が単純噴流に比べて 1 2 段階早まっ た結果とすれば説明がつく. 噴流に対する直交流が存在すると, 大規模渦に遷移するのが早くなると考えられる. また，本研究において，Getsingerの結果よりもストローハル数が大きくなる原因としては，上下噴流の干渉によ る影響が考えられる.

前述したように, Fric(1990)の計測の中で, 噴流剪断層に起因する変動の周波数は, 下流になるに従って 1/2,1/4 倍となっていくことが示されている，これは，K-H 不安定性による渦が，下流に進むにつれて合体することで大 きくなることが原因としている. 本研究においては, 図 11(a)に示した $J=4$ の条件では, 上下の噴流の干渉が弱い ために単一噴流に近いと考えられる，実際の結果においても，噴流基部に存在するピーク周波数 $(1397 \mathrm{~Hz})$ が，流 路中心付近では噴流基部の $1 / 4$ に近い周波数( $300 \mathrm{~Hz}$ 付近)が高くなっており, 単一噴流に近い傾向が得られている. 流路中心付近（下流）において周波数ピークが広くなるのは，噴流の拡散によるものと考えられる. 
図 11 によると，Jが小さくなるに従い，噴流出口における K-H 起因の振動は大きくなっている. この原因とし ては，Rajaratnam(1976)によると，直交流中における噴流では，噴流断面が扁平になることが示されているが，噴 流断面が扁平になると， 円形断面の場合よりも噴流中心から噴流外縁までの距離が減少するために，噴流中心の 速度分布は，噴流外縁で発生する剪断層の影響を受けや寸くなると考えられる。

(b) 直交流による噴流後流の交互渦

Fric と Roshko(1994)によると，直交流中の噴流の後流では，カルマン渦のような交互渦構造が発生することが 示されている.この渦は, 噴流の K-H 不安定性による渦と干渉して複雑な渦構造を形成し, $\mathrm{St}=0.1 \sim 0.2$ となると 述べている. ただし，この交互渦の周波数は，今回の条件においては $15 \mathrm{~Hz}(J=64) \sim 65 \mathrm{~Hz}(J=4)$ と算出され，周波数 分析によって得られたピーク振動周波数とは一致しないため, 本研究における振動は後流渦とは関連性は低いと 考えられるので詳細には議論しない.

(c) 低周波側の変動

図 11 で注目すべき点として，K-H 不安定性と，その 1/2，1/4 倍波では説明できない低周波の変動がある.山 下ら(1987)やChiriac と Ortega(2002)らによると，2 次元噴流においては図 13 のような flapping と呼ばれる左右非 対称に振れる振動現象が研究されており, 低周波の振動周波数であることが示されている. Chiriac らによると, 図 13 のような非対称渦 1 4 の発生原因として, 噴流が壁に衝突する部分によどみ点が形成され，よどみ点位置 が左右に変動することで噴流が”buckling”を起こし，流れが左右に逸れることで非対称性が発生し，その圧力分布 が入口にフィードバックされるとしている. 変動の元としては, 剪断層における不安定性であり, $S t=1.1$ 程度の 振動数を有する. しかし，一番低い低周波側の変動ピークは渦放出の周期よりも低い周波数となっており，St=0.3 程度である. Chiriacらは，このような flapping は，洞列と流路内流れの非線形なカップリングが原因と推測して いるが，さらなる研究が必要であると記している.

また, Thomas ら(1986)によると, flapping ではカルマン渦のような非対称渦列が発生し， St=0.11 程度であると している. 我々の解析での噴流流速と噴流径において $S t=0.11$ は $110 \mathrm{~Hz}$ となるが，図 11 における低周波側のピー クの周波数に近い值となっており, 本解析においても flapping による影響が表れている可能性が高い.

軸対称噴流では，辻本ら(2011)が，噴流噴出方向を周期的に変動させた場合の流れ構造の変化を DNS 解析によ って研究している. 辻本らによると, 変動が無い場合 $(S t=0.0)$ は渦輪が形成され, 下流で崩壊するような通常の噴 流流れだが, $S t=0.01 \sim 0.03$ の変動を与えた場合に, 長い波長の振動が下流で生じるモードが発生し, 本解析にお ける flapping と同様の現象が表れている（注意すべき点として，辻本らは，この非対称の低周波变動を波状(wavy) モードと呼び, flapping は噴流が広範囲に拡散する現象と定義している)。対向噴流が互いに影響を与え合う場合 や主流が存在する場合には，それが外乱となり，軸対称噴流においても低周波の非対称変動が発生する可能性が ある. 本研究においては, (e)において詳細を議論している.

\section{(d) 変動現象の分類}

以上を踏まえて, 各ケースの主要な流速変動ピークを表 3 に表示した. ここで, 主要なピークとは, 特徽的な 振動を表していると思われるものを主観的に選定している. また，K-H 不安定性起因の振動(表中では KH)は図 11 において $1100 \sim 1600 \mathrm{~Hz}$ にあるピークを基準とし, flapping(表中では FL)については, 詳細は後述するが, $146 \mathrm{~Hz}$ 付近のピークを基準と定義した. KH と FLによるピークの高調波, 低調波については分数で乗じて表している. 周波数が完全に一致していない場合もあるが，KH と FLで近い方を該当ピークとして分類した. 異なる原因とし ては，主流と対向噴流の相互作用により，局所流速が変化している影響と考えられる. ”C”が接頭語のピークは 噴流衝突部付近, ”NJ”が接頭語のピークは噴流出口付近を表し，ピークの強さの順番に $\mathrm{f} 1, \mathrm{f} 2, \mathrm{f} 3$ と命名した.

噴流出口付近では K-H 不安定性による変動が強いが， $J=16,36,64$ では, flapping と思われる低周波側の変動も 確認できる．一方，噴流衝突部付近では，J=4では K-H の 1/4 倍が確認できる．J=9 では K-H の 1/2 倍と flapping の 2 倍が明確に確認できるが, $336 \mathrm{~Hz}$ にもピークが存在する.これは, 若干の周波数のズレはあるが, K-H の $1 / 4$ 倍波と flapping の 2 倍波が重なったことで強められたのではないかと考えられる.J=16,36,64では K-H 不安定の 影響は小さくなり, flappingによる周波数が支配的となっている. 
(e) 低周波側振動のメカニズム推測

ここで, 流れとして，図 14 のように，噴流が衝突したあとに再循環して噴流基部まで戻る循環を考える. 左側 から直交流が流れてくるため，噴流右側の循環は，明示的に流れが元に戻るという意味では存在しないが，流体 力学の定義としての循環と考えれば，存在すると考えられる。このような循環があれば，噴流衝突による流れの 変動が噴流基部にフィードバックされるため, 特定の周波数での振動が高くなると考えられる. 実際に, $J=16$ の 場合の例を図 15 に示寸. 衝突によって発生した高流速領域が循環によって噴流基部へ移動する様子がわかる. こ の周期としては， $1 / 0.0006 \mathrm{sec}=$ 約 $166 \mathrm{~Hz}$ となり，得られたピーク周波数の $146 \mathrm{~Hz}$ に近いものとなっているため, この循環が変動の主な原因であると強く示唆される.

(f) 変動の強度と流れ場の形態についての考察

図 16 に, 噴流衝突部付近における速度変動 (図 11 の結果) を 0 2500Hz まで積分した結果を示す.この結果, 衝突部の変動は $J=4$ で最も低いが, $J=9$ では急激に上昇し, 最も高くなる. それ以上の場合には滑らかに減少す るが，J=36 以上では一定の值になる傾向が確認できる. これは，図 3 に示した流れ場の分類のとおり，J=9 にお いて上下にスイッチングするような流れが生じているときに最も変動が高く, 円盤状ジェットの形成されるモー ドでは一定の変動になることを示している．この結果より，対向噴流の流れの分類は，(1)J=4では互いが干渉し ないモード，(2) $J=9$ では噴流がスイッチングするモード，(3) $J=36,64$ では衝突面に円盤状ジェットが生成されるモ ードの 3 つに分類でき, $J=16$ はスイッチングと円盤状ジェットの間の遷移状態と考えることが自然であると考え られる。 


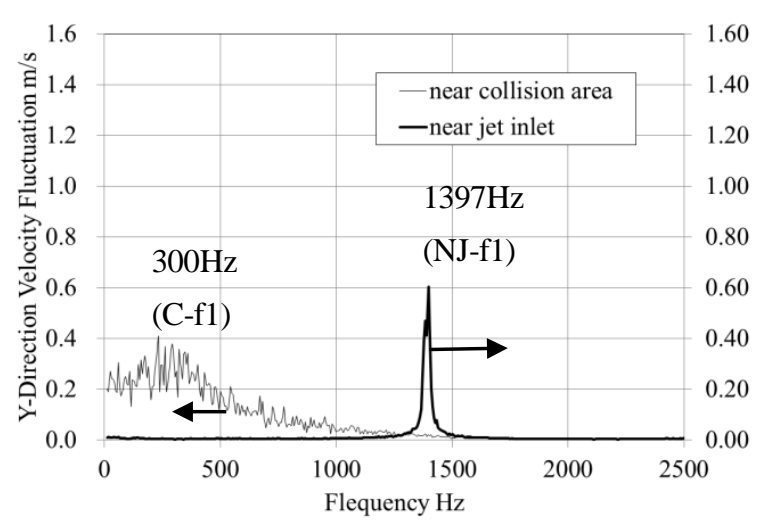

(a) $J=4$

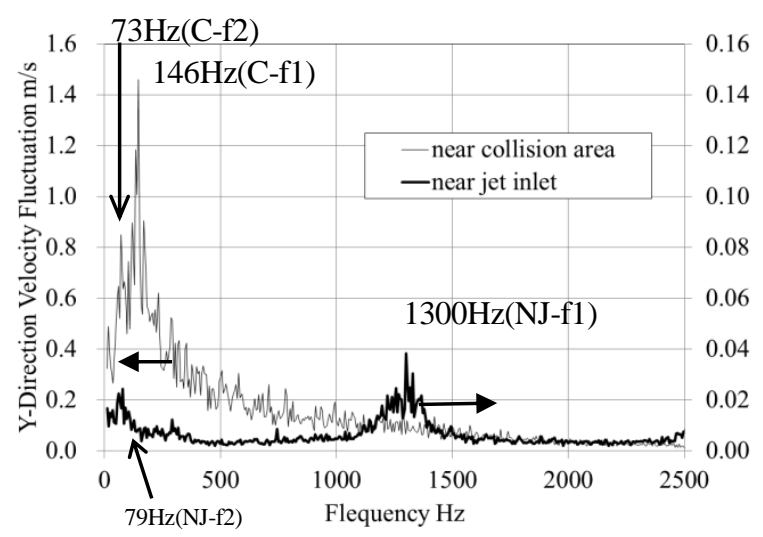

(c) $J=16$

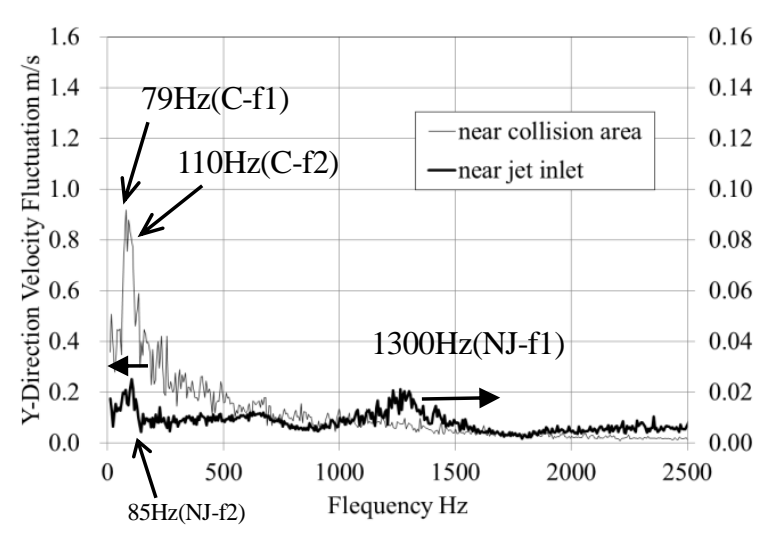

(e) $J=64$

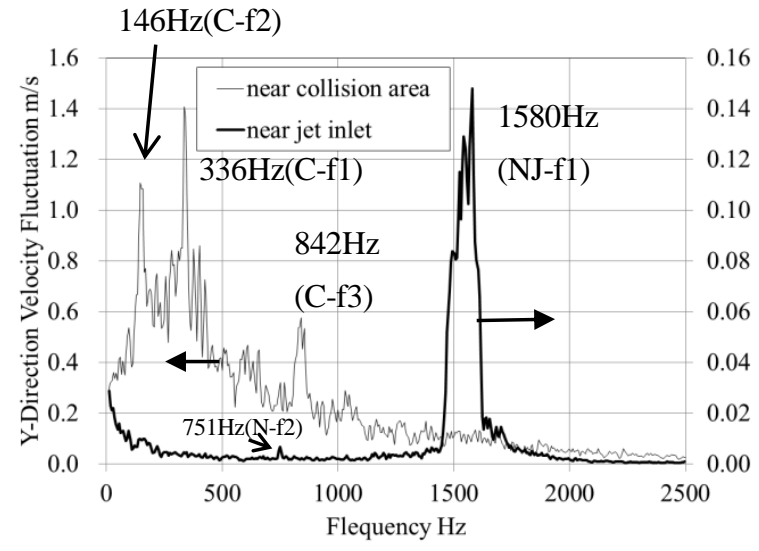

(b) $J=9$

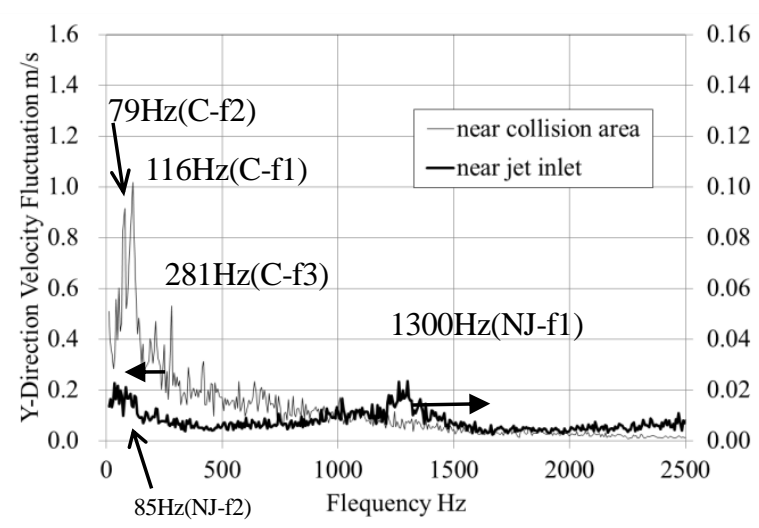

(d) $J=36$

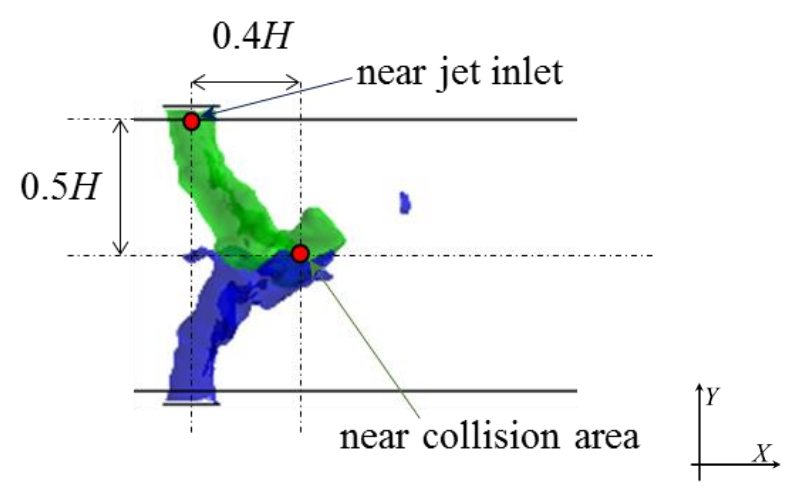

(f) measurement points

Fig.11 FFT results of Y-direction velocity fluctuation at near jet inlet and near collision area. The Kelvin-Helmholtz instability and low frequency fluctuation exist. 
Table 3 Characteristic peak values of FFT results (in Fig.11).

\begin{tabular}{|l|l|l|l||l|l|}
\hline & C-f1 & C-f2 & C-f3 & NJ-f1 & NJ-f2 \\
\hline \multirow{3}{*}{$J=4$} & $300 \mathrm{~Hz}$ & & & $1398 \mathrm{~Hz}$ & \\
& $0.4 \mathrm{~m} / \mathrm{s}$ & & & $0.6 \mathrm{~m} / \mathrm{s}$ & \\
& $(\mathrm{KH} \times 1 / 4)$ & & & $(\mathrm{KH})$ & \\
\hline \multirow{5}{*}{$J=9$} & $336 \mathrm{~Hz}$ & $146 \mathrm{~Hz}$ & $842 \mathrm{~Hz}$ & $1580 \mathrm{~Hz}$ & $751 \mathrm{~Hz}$ \\
& $1.4 \mathrm{~m} / \mathrm{s}$ & $1.1 \mathrm{~m} / \mathrm{s}$ & $0.58 \mathrm{~m} / \mathrm{s}$ & $0.15 \mathrm{~m} / \mathrm{s}$ & $0.008 \mathrm{~m} / \mathrm{s}$ \\
& $(\mathrm{KH} \times 1 / 4, \mathrm{FL} \times 2)$ & $(\mathrm{FL} \times 1)$ & $(\mathrm{KH} \times 1 / 2)$ & $(\mathrm{KH})$ & $(\mathrm{KH} \times 1 / 2)$ \\
\hline \multirow{5}{*}{$J=16$} & $146 \mathrm{~Hz}$ & $73 \mathrm{~Hz}$ & & $1300 \mathrm{~Hz}$ & $79 \mathrm{~Hz}$ \\
& $1.43 \mathrm{~m} / \mathrm{s}$ & $0.82 \mathrm{~m} / \mathrm{s}$ & & $0.04 \mathrm{~m} / \mathrm{s}$ & $0.025 \mathrm{~m} / \mathrm{s}$ \\
& $(\mathrm{FL})$ & $(\mathrm{FL} \times 1 / 2)$ & & $(\mathrm{KH})$ & $(\mathrm{FL} \times 1 / 2)$ \\
\hline \multirow{3}{*}{$J=36$} & $116 \mathrm{~Hz}$ & $79 \mathrm{~Hz}$ & $281 \mathrm{~Hz}$ & $1300 \mathrm{~Hz}$ & $85 \mathrm{~Hz}$ \\
& $1.0 \mathrm{~m} / \mathrm{s}$ & $0.9 \mathrm{~m} / \mathrm{s}$ & $0.52 \mathrm{~m} / \mathrm{s}$ & $0.02 \mathrm{~m} / \mathrm{s}$ & $0.02 \mathrm{~m} / \mathrm{s}$ \\
& $(\mathrm{FL} \times 3 / 4)$ & $(\mathrm{FL} \times 1 / 2)$ & $(\mathrm{FL} \times 7 / 4)$ & $(\mathrm{KH})$ & $(\mathrm{FL} \times 1 / 2)$ \\
\hline \multirow{2}{*}{$J=64$} & $79 \mathrm{~Hz}$ & $110 \mathrm{~Hz}$ & & $85 \mathrm{~Hz}$ & $1300 \mathrm{~Hz}$ \\
& $0.9 \mathrm{~m} / \mathrm{s}$ & $0.9 \mathrm{~m} / \mathrm{s}$ & & $(\mathrm{FL} \times 3 / 4)$ & \\
& $(\mathrm{FL} \times 1 / 2)$ & $(\mathrm{FL} \times 1 / 2)$ & $(\mathrm{KH})$ \\
\hline
\end{tabular}

KH: Kelvin Helmholtz, FL: flapping
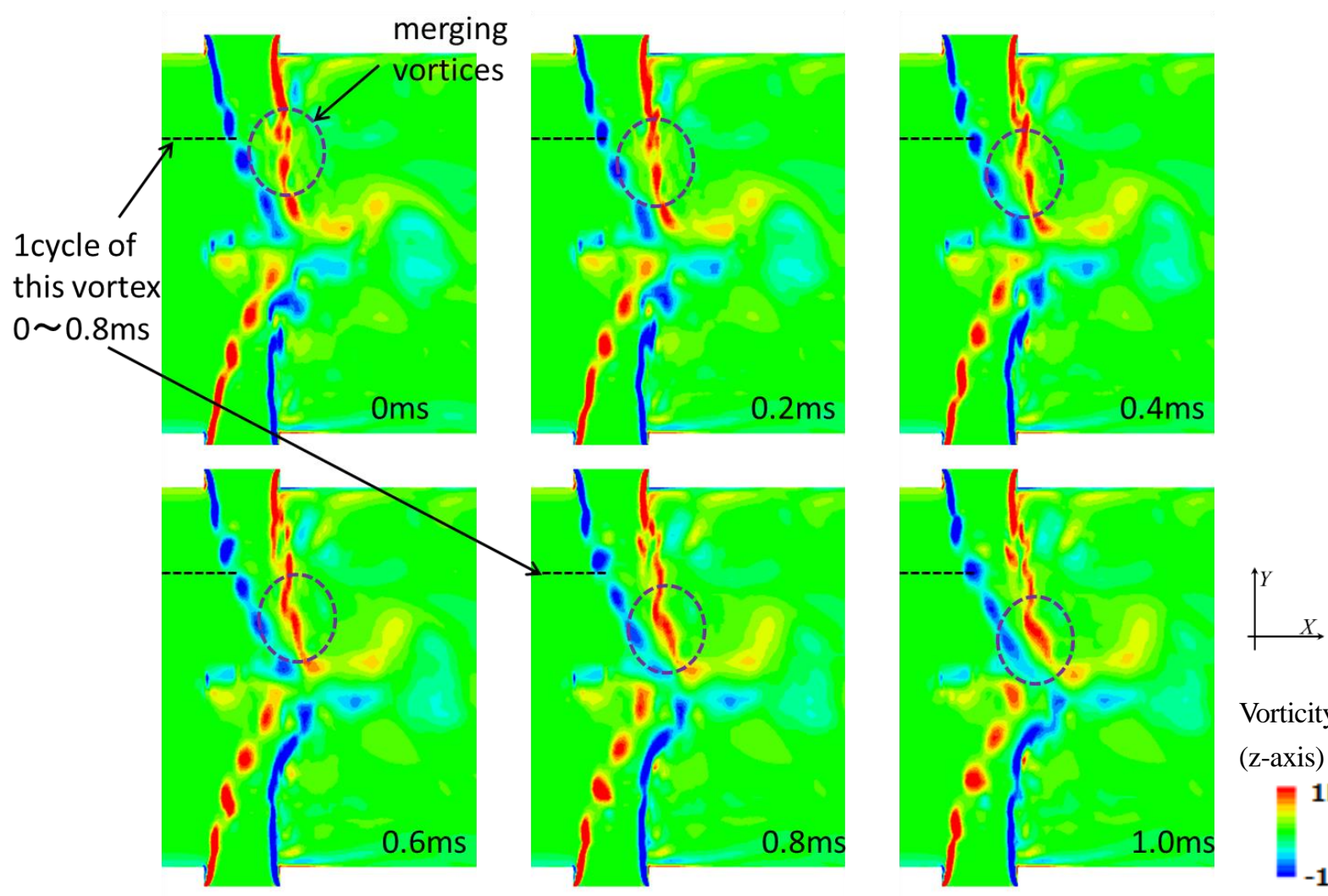

Vorticity (z-axis)

Fig.12 Time sequence images of vorticity (Z-axis). The vortices are merging at $0.8 \sim 1.0 \mathrm{~ms}$ (XY-plane) $(J=9)$. 


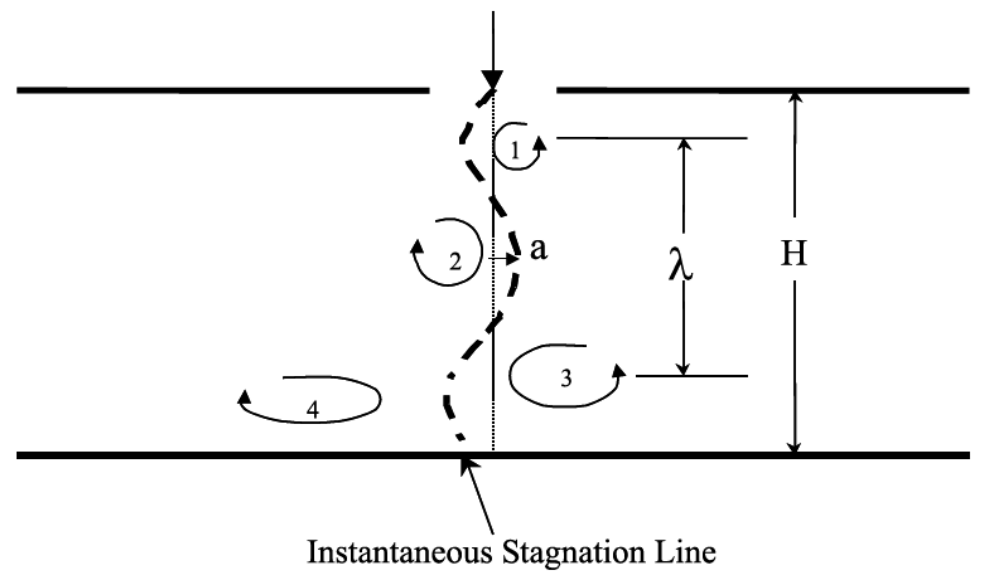

Fig.13 Pictorial jet vortex dynamics (flapping instability) (Chiriac and Ortega,2002).

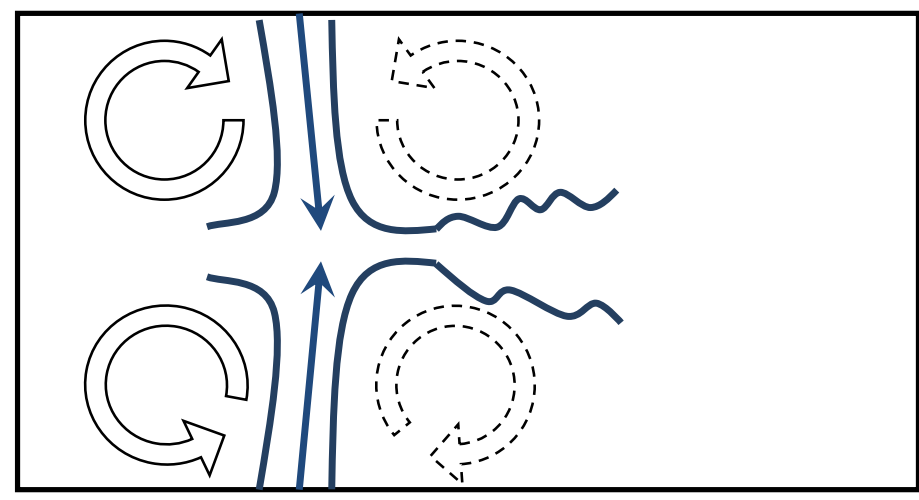

Fig.14 Circulation flows.
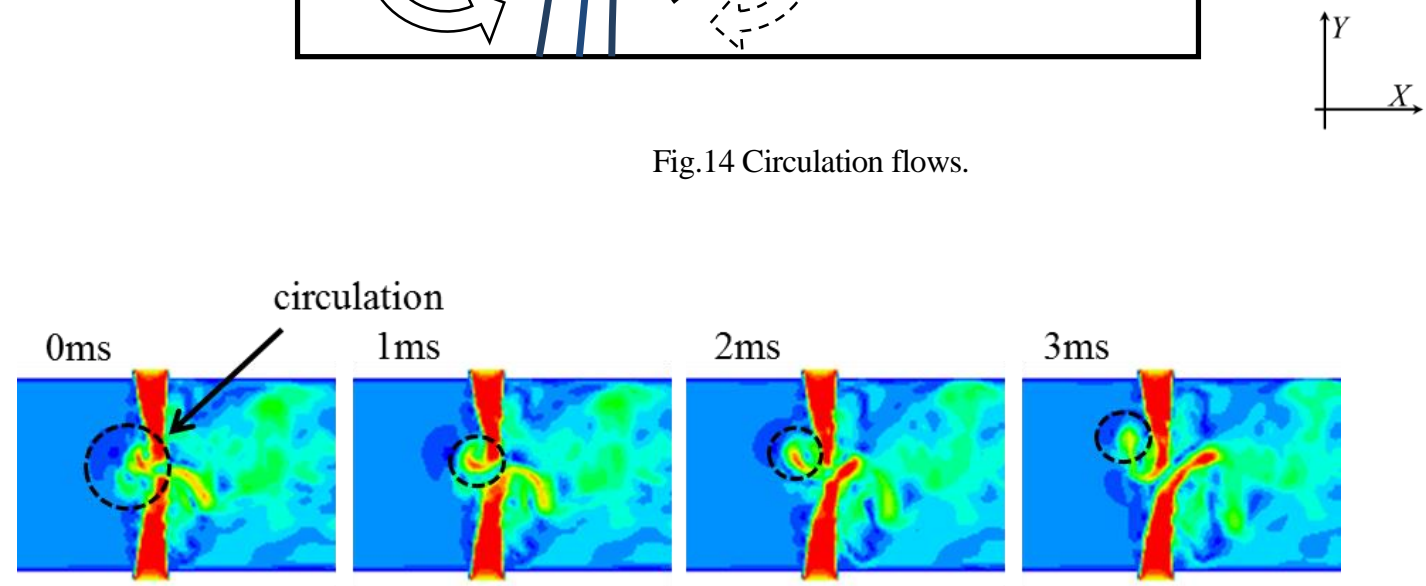

circulation
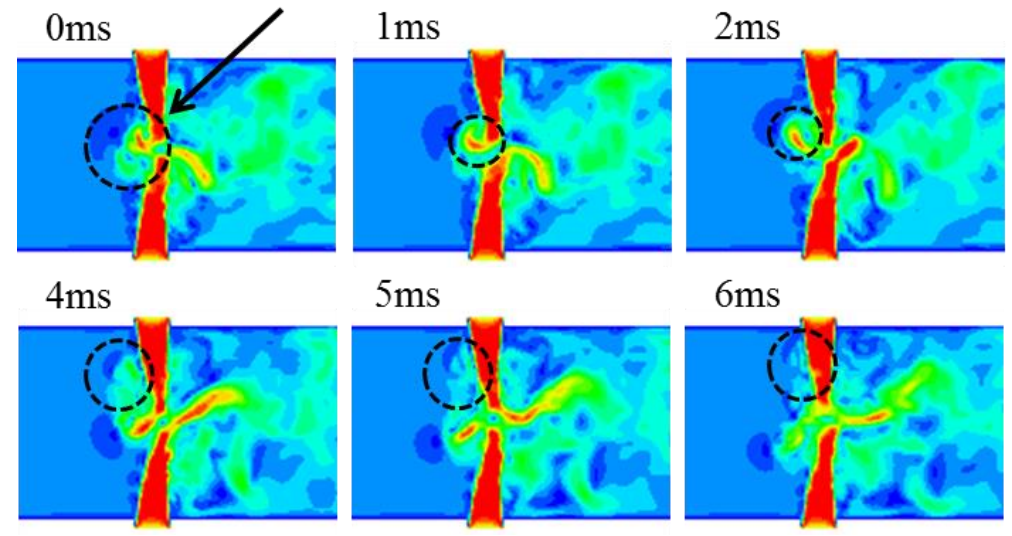

$3 \mathrm{~ms}$
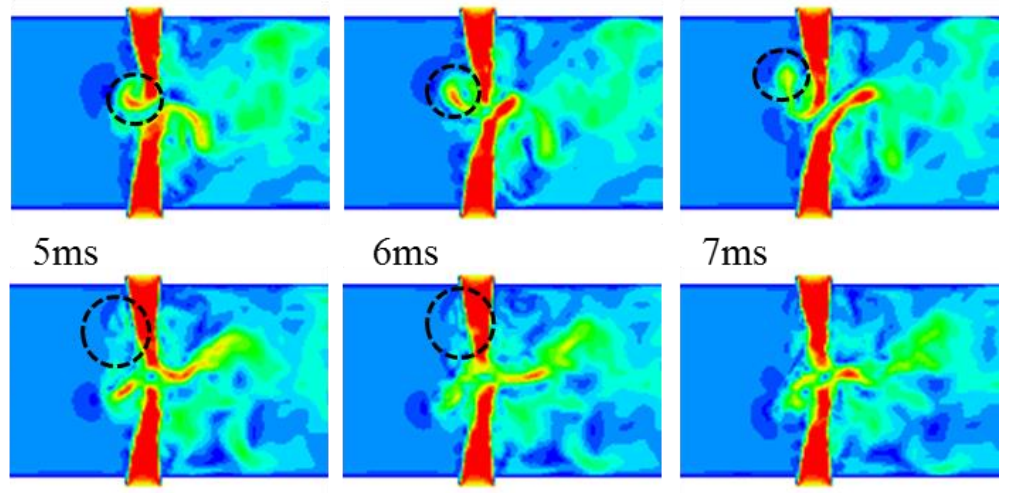

$7 \mathrm{~ms}$

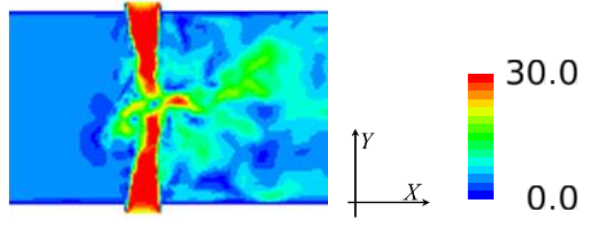

Fig. 15 Circulation flows of $J=16$ (velocity magnitude). The low frequency fluctuation is related to the circulation which is caused from the collision between opposed jets. 


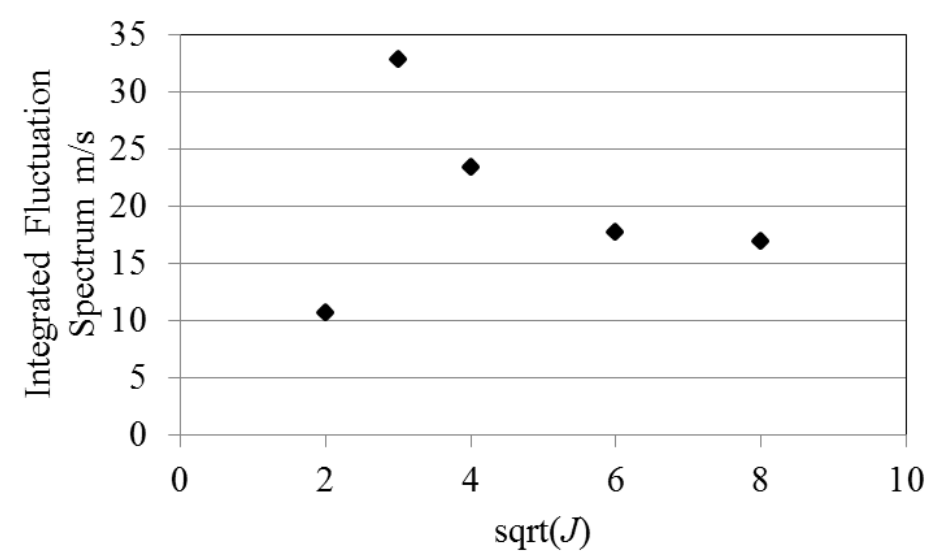

Fig.16 The integrated values of velocity fluctuation spectrum near collision area.

\section{5. 結論}

上下 $2 つ の$ 噴流とそれに直交する主流を有する流れで，孔間隔 $\mathrm{S}$ ，流路高さ $\mathrm{H}$ を同一とした条件において，噴 流と直交流の運動量流束比 $J$ を変化させた解析を行うことで，混合挙動の検討を行った．その結果，以下の結果 が得られた。

・先行研究(Nagao,2014)でも示した通り，Jが異なると流れ場の形態が異なる

・ 噴流の変動要因として, 剪断層のケルビン・ヘルムホルツ $(\mathrm{K}-\mathrm{H})$ 不安定性に起因する振動と, 噴流が噴出方 向と垂直な方向に，非対称に振れる振動である flapping が確認できた.

・ 噴流入口付近では, K-H 不安定性による変動が大きい. $J=16,36,64$ では flapping によるものと思われる低周 波振動も確認できる.

・ $J=4$ の噴流衝突部では K-H の $1 / 4$ 周波数の変動が高い.これは, 直交流に流入する単一噴流に見られる特徵 であり，下流に進むにつれて渦が合体し，周波数が $1 / 2$ 倍されていくことが原因である.

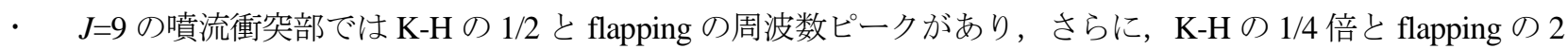
倍付近の周波数が重なる部分で強いピークが存在する.

・ $J=16,36,64$ の噴流衝突部では，K-H の影響は小さくなり，flappingによる振動が支配的となっている.

· この系における flapping の要因として, 噴流衝突に起因寸る循環流によるフィードバックが考えられる.

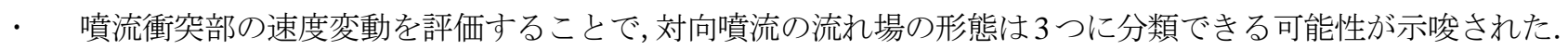




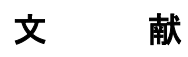

Chiriac, V. A. and Ortega, A., A numerical study of the unsteady flow and heat transfer in a transitional confined slot jet impinging on an isothermal surface, International Journal of Heat and Mass Transfer, Vol. 45(2002), pp.1237-1248.

Fric, T.F., Structure in the near field of the transverse jet, California Institute of Technology Doctor Thesis(1990).

Fric, T.F. and Roshko, A., Vortical structure in the wake of a transverse jet, Journal of Fluid Mechanics, Vol.279(1994), pp. $1-47$.

Getsinger, D., Shear layer instabilities and mixing in variable density transverse jet flows, UCLA Electric Theses and Dissertations (2012).

Hallagi, M. and Mazaheri, K., Comparison of LES and RANS in numerical simulation of turbulent non-premixed flame under MILD combustion condition, Proceedings of 7th Mediterranean Combustion Symposium,TC-12(2011).

Holdeman, J. D., Walker, R. R. and Kors, D. L., Mixing of multiple dilution jets with a hot primary airstream for gas turbine combustors, AIAA Paper 73-1249 (1973).

Lefebvre, A. H. and Ballal, D.R., Gas Turbine Combustion Third Edition, CRC Press (2010).

Liscinsky, D. S., True, B. and Holdeman, J. D., Experimental study of cross-stream mixing in a rectangular duct, NASA Technical Memorandum 105694, AIAA-92-3090 (1992).

Mack, A. and Spruijt, M.P.N., Validation of OpenFOAM for heavy gas dispersion applications, Journal of Hazardous Materials, Vol. 262(2013), pp.504-516.

Nagao, T., Matsuno, S. and Hayashi, A.K, Effect of cross-flow momentum on opposing jet mixing, International Journal of Gas Turbine, Propulsion and Power Systems, Vol.6, No.3(2014), pp.1-8.

長尾 隆央，松野 伸介，林 光一，矩形流路内での対向噴流による流体混合，日本ガスタービン学会誌，Vol.41， No.6(2013), pp.506-511.

Poinsot, T. and Veynante, D. Theoretical and numerical combustion second edition, Edwards (2005)

Rajaratnam, N., Turbulent jets, Elsevier Scientific Publishing Company (1976).

Shekarian, A. A., Tabejamaat, S. and Shoraka, Y., Effects of incident shock wave on mixing and flame holding of hydrogen in supersonic air flow, International journal of Hydrogen Energy, Vol 39(2014), pp.10284-10292.

Thomas, F.O. and Goldschmidt, V.W., Structural characteristics of a developing turbulent planar jet, Journal of Fluid Mechanics., Vol. 163(1986), pp. 227-256.

豊田 国昭, 噴流の渦, ながれ, Vol.24 (2005), pp.151-160.

辻本 公一, 青 孝次, 社河内 敏彦, 安藤 敏剛, DNS によるベクトル制御された自由噴流の構造と混合特性に関す る検討, 日本機械学会論文集 B 編, Vol.77, No.775 (2011), pp.537-545.

Vranos, A., Lincinsky, D.S., True, B. and Holdeman, J.D., Experimental study of cross-stream mixing in a cylindrical duct, NASA Technical Memorandum 105180, AIAA-91-2459, 1991.

山下 博史, 王 炎, 泉 亮太郎, 二次元対向噴流における流動および伝熱（第 1 報, 非定常挙動に関する実験），日 本機械学会論文集 B 編, Vol.53, No.496 (1987), pp.3729-3736.

\section{References}

Chiriac, V. A. and Ortega, A., A numerical study of the unsteady flow and heat transfer in a transitional confined slot jet impinging on an isothermal surface, International Journal of Heat and Mass Transfer, Vol. 45(2002), pp.1237-1248.

Fric, T.F., Structure in the Near Field of the Transverse Jet, California Institute of Technology Doctor Thesis(1990).

Fric, T.F. and Roshko, A., Vortical structure in the wake of a transverse jet, Journal of Fluid Mechanics, Vol.279(1994), pp. 1-47.

Getsinger, D., Shear layer instabilities and mixing in variable density transverse jet flows, UCLA Electric Theses and Dissertations (2012).

Hallagi, M. and Mazaheri, K., Comparison of LES and RANS in numerical simulation of turbulent non-premixed flame under MILD combustion condition, Proceedings of 7th Mediterranean Combustion Symposium,TC-12(2011).

Holdeman, J. D., Walker, R. R. and Kors, D. L., Mixing of multiple dilution jets with a hot primary airstream for gas turbine combustors, AIAA Paper 73-1249 (1973).

Lefebvre, A. H. and Ballal, D.R., Gas Turbine Combustion Third Edition, CRC Press (2010).

Liscinsky, D. S., True, B. and Holdeman, J. D., Experimental study of cross-stream mixing in a rectangular duct, NASA Technical Memorandum 105694, AIAA-92-3090 (1992). 
Mack, A. and Spruijt, M.P.N., Validation of OpenFOAM for heavy gas dispersion applications, Journal of Hazardous Materials, Vol. 262(2013), pp.504-516.

Nagao, T., Matsuno, S. and Hayashi, A.K, Effect of cross-flow momentum on opposing jet mixing, International Journal of Gas Turbine, Propulsion and Power Systems, Vol.6, No.3(2014), pp.1-8.

Nagao, T., Matsuno, S. and Hayashi, A.K., Fluid mixing of opposed jet flows in the rectangular duct, Journal of gas turbine socirty of Japan, Vol.41, No.6(2013), pp.506-511(in Japanese).

Poinsot, T. and Veynante, D. Theoretical and numerical combustion second edition, Edwards (2005)

Rajaratnam, N., Turbulent jets, Elsevier Scientific Publishing Company (1976).

Shekarian, A. A., Tabejamaat, S. and Shoraka, Y., Effects of incident shock wave on mixing and flame holding of hydrogen in supersonic air flow, International journal of Hydrogen Energy, Vol 39(2014), pp.10284-10292.

Thomas, F.O. and Goldschmidt, V.W., Structural characteristics of a developing turbulent planar jet, Journal of Fluid Mechanics., Vol. 163(1986), pp. 227-256.

Toyoda, K., Vortices in jets, Nagare, Vol.24 (2005), pp.151-160 (in Japanese).

Tsujimoto, K., Ao, K., Shakouchi T. and Ando T., Numerical investigation on flow structures and mixing performances of vector-controlled free jet using DNS, Transactions of Japan Society Mechanical Engineers, Series B, Vol.77, No.775(2011), pp.537-545 (in Japanese).

Vranos, A., Lincinsky, D.S., True, B. and Holdeman, J.D., Experimental study of cross-stream mixing in a cylindrical duct, NASA Technical Memorandum 105180, AIAA-91-2459, 1991.

Yamashita, H., Wang, Y. and Izumi, R., Fluid flow and heat transfer in an opposed plane jet in a uniform stream (1st report, experiment in unsteady motions), Transactions of the Japan Society Mechanical Engineers Series B, Vol.53, No.496(1987), pp.3729-3736 (in Japanese). 